\title{
Prevalence of ankyloglossia in newborns and impact of frenotomy in a Baby-Friendly Hospital
}

\author{
Paula M. Barberá-Pérez ${ }^{1 *}$, Montserrat Sierra-Colomina ${ }^{1}$, Nyulyufer Deyanova-Alyosheva ${ }^{2}$, \\ Mariano Plana-Fernández ${ }^{1}$, and Paula Lalaguna-Mallada ${ }^{1}$ \\ ${ }^{1}$ Servicio de Pediatría; ${ }^{2}$ Enfermería del Servicio de Pediatría. Hospital de Barbastro, Huesca, Spain
}

\begin{abstract}
Background: Ankyloglossia is a condition present in some newborns and can be associated with breastfeeding difficulties, leading to symptoms in the child and the mother. This study aimed to analyze the characteristics of newborns with tongue-tie and the symptoms reported by their mothers, and the short and long-term outcomes of frenotomy. Methods: We conducted a prospective and observational 7-month study in a Baby-Friendly Hospital (BFH). We included all the breastfed newborns without comorbidities that underwent a frenotomy. Results: $A$ total of 33 frenotomies were performed. The most common findings before the procedure were maternal breastfeeding pain (29/33), ineffective latch (18/33), and maternal nipple lesions (18/33). We observed that newborns surgically intervened later showed a high incidence of jaundice $(p=0.03)$, weight loss greater than $10 \%$ at hospital discharge $(p=0.004)$, and their mothers experienced pain more often $(p=0.004)$. At one month of age, there was an improvement in breastfeeding-related pain $(p=0.012)$ and its intensity $(p=0.016)$, the presence of maternal cracked nipples $(p<0.01)$, and latching on $(p<0.01)$. Conclusions: Ankyloglossia can prevent the correct establishment of breastfeeding. Frenotomy is associated with few complications, and when appropriately indicated, may have a positive impact on breastfeeding, reducing maternal pain, the presence of nipple lesions, and latching problems.
\end{abstract}

Keywords: Ankyloglossia. Tongue-tie. Frenotomy. Breastfeeding. Lactation.

\section{Prevalencia de la anquiloglosia en el recién nacido e impacto de la frenotomía en un hospital de la Iniciativa para la Humanización de la Asistencia al Nacimiento y la Lactancia}

\section{Resumen}

Introducción: La anquiloglosia está presente en algunos recién nacidos y puede interferir en el amamantamiento, produciendo sintomatología en el niño y en la madre. El objetivo de este estudio fue analizar las características de los recién nacidos con anquiloglosia, así como la sintomatología referida por sus madres, y la evolución tras la frenotomía. Métodos: Estudio observacional analítico prospectivo de las frenotomías realizadas en la planta de maternidad de un hospital IHAN (Iniciativa para la Humanización de la Asistencia al Nacimiento y la Lactancia) durante 7 meses. Se incluyeron todos los recién nacidos alimentados inicialmente con lactancia materna a quienes se realizó una frenotomía. Resultados: Se realizaron

Correspondence:

*Paula M. Barberá-Pérez

E-mail: pmbarbera@salud.aragon.es

Available online: 17-09-2021

Date of reception: $26-11-2020$ Date of acceptance: 12-04-2021 DOI: 10.24875/BMHIM.20000391
Bol Med Hosp Infant Mex. 2021;78(5):418-423

www.bmhim.com 1665-1146/C 2021 Hospital Infantil de México Federico Gómez. Published by Permanyer. This is an open access article under the CC BY-NC-ND license (http://creativecommons.org/licenses/by-nc-nd/4.0/). 
33 frenotomías. Los hallazgos más frecuentes previos a la frenotomía fueron dolor con las tomas (29/33), dificultad en el agarre (18/33) y presencia de grietas (18/33). Asimismo, se vio que los pacientes intervenidos más tarde presentaban con mayor frecuencia ictericia $(p=0.03)$ y pérdida de peso superior al 10\% previa al alta $(p=0.004)$, y sus madres presentaron dolor con mayor frecuencia $(p=0.004)$. Al mes de vida se observó la mejoría del dolor con las tomas $(p=0.012)$ y su intensidad $(p=0.016)$, la presencia de grietas $(p<0.01)$ y el agarre al pecho $(p<0.01)$. Conclusiones: La anquiloglosia puede impedir el correcto establecimiento de la lactancia materna. La frenotomía presenta escasas complicaciones y, cuando está bien indicada, puede mejorar el amamantamiento, reduciendo el dolor, la presencia de grietas y las dificultades en el agarre.

Palabras clave: Anquiloglosia. Frenillo lingual corto. Frenotomía. Lactancia materna. Lactancia.

\section{Introduction}

Ankyloglossia (also known as lingual frenulum, tonguetie, or tongue-tied tongue) is defined as a membrane that holds the tongue at the lower midline ${ }^{1}$. Depending on the attachment, it can be anterior or posterior ${ }^{2}$ :

- Ankyloglossia type I (anterior): the location is the tip of the tongue, giving it a heart shape when viewed anteriorly. The frenulum produces a restriction of the free movement of the tongue, preventing it from elevating and extending.

- Ankyloglossia type II (anterior): it is found further back from type 1, about 2-4 $\mathrm{mm}$ away from the tip of the tongue. It is moderately restrictive, allowing elevation and extension of the tongue, although not in its entirety.

- Ankyloglossia type III (posterior): it is located further back than the positions described above. It allows extension of the tongue but not its elevation and has a submucosal component.

- Ankyloglossia type IV or submucosal frenulum (posterior): the frenulum is not easily visible because it is located below the submucosal tissue. If there is movement, it is asymmetric, and when opening the mouth, the tongue and mouth become twisted. It almost totally impedes the movement of the tongue.

Physical features of the oral anatomy and tongue functionality are considered for diagnosis. The Hazelbaker descriptive assessment instrument is the most used tool for the diagnosis of ankyloglossia ${ }^{3}$. It consists of five items regarding the aspect of the tongue and seven items related to its function, each of which is scored from 2 to 0 . A total score of $\leq 8$ for aspect or $\leq 11$ for function are predictors of frenotomy.

Effective coordination between suckling, swallowing, and breathing is necessary for the newborn to feed appropriately. This process is influenced by tongue movements (extension, elevation, lateralization, peristaltic movements), so newborns with ankyloglossia have difficulties in breastfeeding ${ }^{4-6}$.
A variety of symptoms can be observed in both the mother and the infant. The mother presents breastfeeding-related pain (with or with no cracked nipples), and the deficient stimulation of the breast by the newborn hinders milk production or produces an inadequate emptying of the breasts, which can lead to mastitis. Furthermore, the newborn suffers from lack of weight gain, takes very long feedings (some feedings overlap with the following ones), gets "irritated" with the breast, does not hold it well, develops lactation callus, chokes very often, makes noise when sucking (clicks) and has hollow cheeks $s^{4,6,7}$.

The treatment for ankyloglossia is frenotomy, a minor procedure in which sterile scissors cut and release the frenulum to ensure proper tongue mobility. As it is a quick and minimally painful technique, anesthesia is not usually used. It is a simple, safe procedure with minimal risks, which may cause a small amount of local bleeding. Other risks that may occur, although very exceptionally, are bleeding, infection, pain, ulceration, lesions in the tongue and submandibular ducts, and ineffectiveness of the treatment due to fibrosis or recurrence of the frenulum ${ }^{5,8}$.

Depending on the center, frenotomy may be associated with an evaluation and follow-up by a breastfeeding specialist. Furthermore, after the intervention, exercises for rehabilitating the tongue musculature are usually explained and given ${ }^{5,9}$.

In most cases, immediate relief of the mothers' pain is observed. In the days following the intervention, improvement is observed in all other aspects ${ }^{4,8,10}$.

This study aimed to analyze the characteristics of newborns with ankyloglossia, as well as the symptoms reported by their mothers, and to see the evolution of different manifestations such as breastfeeding-related pain, its intensity, latching problems, cracked nipples, mastitis, jaundice, and weight stagnation one month after frenotomy. 


\section{Methods}

We conducted a prospective analytical observational study of frenotomies performed in the maternity ward of a BFH (Baby-Friendly Hospital). Frenotomies were performed in the first days of life, before discharge, over 7 months (February 2019 to August 2019). All 33 patients who were breastfed and with no associated comorbidities were included in the study.

Newborns with artificial feeding, comorbidities, and those who underwent frenotomy after discharge from the maternity ward were excluded from the study.

A survey was applied to the mothers to record the most frequent symptoms associated with ankyloglossia, both in the newborns and mothers. The visual analog scale was used in those mothers who presented pain: 0-2 mild pain, 3-7 moderate, and 8-10 intense. Other data such as birth weight, age when the frenotomy was documented, sex, and type of frenulum were also recorded. According to the Coryllos et al. ${ }^{2}$ anatomical scale, the type of frenulum was defined, and the functional evaluation was performed using the Hazelbaker tool ${ }^{3}$. Excessive weight loss was defined as more than $10 \%$ of the birth weight before discharge from the maternity ward.

During the first hours of life, an early frenotomy was advised to the family of those patients who presented significant ankyloglossia with frenulum type I, regardless of the associated symptoms. For the rest of the patients, the functional evaluation and the symptomatology reported by the mother were also considered.

Informed parental consent to include the patient's data in the study was obtained in written form before performing the frenotomy. The ethics committee of the hospital approved the study.

One month after the frenotomy, families were contacted to evaluate the issues recorded at the time of the frenotomy and to assess any changes. In addition, the newborn's type of feeding and weight were also examined.

The data were analyzed with the Statistical Package for Social Science Software (SPSS), IBM ${ }^{\circ}$ version 19.0. The dispersion of quantitative variables was expressed as mean and standard deviation (SD) or range, using absolute and relative frequencies for qualitative variables. The Kolmogorov-Smirnov test was used to test the normality of the distribution of the variables under study. The statistical difference between group means was compared with the nonparametric Mann-Whitney test. The nonparametric Kruskal-Wallis test was used with variables having at least three categories. Analysis of serial determinations of a nonparametric quantitative variable was performed using the Wilcoxon rank-sum test. Qualitative variables were analyzed using a Pearson's $\chi^{2}$ test when possible (Fisher's exact test if the expected value per group was $<5$ ). The Mc Nemar's $\chi^{2}$ test was used to compare the paired qualitative variables. $p$-values $<0.05$ ts were considered statistically significant.

\section{Results}

During the study period, 305 infants were born, and 36 cases of ankyloglossia were detected (11.7\%). Thirty-three frenotomies were performed on the maternity ward $(10.8 \%)$ in 18 males (18/33; 54.4\%) and 15 females (15/33; 45.5\%). In most cases, newborns received breastfeeding (32/33; 97\%). Only one of the newborns (NB) received mixed feeding $(1 / 33 ; 3 \%)$. Frenotomy was not required in three asymptomatic NBs with ankyloglossia.

In NBs who required frenotomy, the most frequent type of ankyloglossia was type II (15/33; 45.4\%), followed by type III (8/33, $24.2 \%)$, type IV $(6 / 33,18.2 \%)$, and type I (4/33, 12.1\%).

No medium- or long-term complications of the procedure were recorded. Only one case $(1 / 33 ; 3 \%)$ attend consultation for irritability 24 hours after frenotomy, which was self-limited after some days.

The mean age of intervention was at one day of life, being the earliest at 4 hours of life and the latest at 6 days. The NBs were born between week 36 and week $41+3$, with a mean gestational age of 39 weeks \pm 1 '39. The weight of the newborns ranged from $2380 \mathrm{~g}$ to $4540 \mathrm{~g}$, with a mean of $3224 \pm 489 \mathrm{~g}$.

Regarding the symptomatology associated with ankyloglossia before frenotomy, the most frequent findings were breastfeeding-related pain (29/33; 87.9\%), difficulty in latching $(18 / 33 ; 54.5 \%)$, and cracked nipples (18/33; $54.5 \%)$. There were no cases of mastitis. Jaundice was observed in six NBs $(6 / 33 ; 18.2 \%)$ and weight loss $>10 \%$ in three NBs (3/33; $9.1 \%)$.

The mothers with pain reported moderate to severe intensity (the mean value on the visual analog scale was 7 , ranging from 5 to 9) (Table 1).

When analyzing the previously described data, no significant differences were observed between the type of frenulum and the age at which frenotomy was performed (Kruskal Wallis 4.219, $p=0.239$ ). Furthermore, breastfeeding-related pain tended to be higher with type II frenulum (Fisher 5.083, $p=0.096$ ). Also, cracked nipples were more frequently present in mothers of 
Table 1. Pain intensity before frenotomy

\begin{tabular}{|l|l|c|c|c|c|c|c|c|}
\hline & & $\mathbf{n}$ & $\%$ & Mean & Median & Minimum & Maximum & SD \\
\hline Without pain & & 4 & 12.1 & & & & \\
\hline \multirow{2}{*}{ With pain } & Mild (0-2) & 0 & 0 & 0 & 0 & 0 & 0 & 0 \\
\hline & Moderate (3-7) & 19 & 57.6 & 7 & 7 & 5 & 7 & 1 \\
\hline
\end{tabular}

SD, standard deviation.

children with frenulum types II, III, and IV compared with type I (Fisher 7.861, $p=0.042$ ). We also observed that patients who underwent surgery later in life presented jaundice (Mann-Whitney's U-test 29, $p=0.013$ ) and excessive weight loss more frequently (MannWhitney's U-test $4.5, p=0.004)$, and their mothers presented pain more frequently (Mann-Whitney's U-test $20, p=0.035$ ) as well.

\section{Follow-up at one month of life}

At one month of life, 19 of the infants continued to be exclusively breastfed (19/33; 57.6\%), six with mixed lactation (6/33; $18.2 \%)$, and eight with artificial lactation $(8 / 33 ; 24.2 \%)$. Of the latter group, three abandoned breastfeeding because latching problems persisted, and five because of maternal decision, with no other associated problem.

Regarding mothers with exclusive breastfeeding or mixed lactation at one month of life, we found difficulty with latching $(5 / 25 ; 20 \%)$, breastfeeding-related pain $(8 / 25 ; 32 \%)$, and cracked nipples $(3 / 25 ; 12 \%)$ (Table 2$)$. These results represent a statistically significant improvement in these items (McNemar $p=0.012, p<$ 0.01 , and $p<0.01$, respectively).

Most of the mothers did not report breastfeeding-related pain. However, the pain scores ranged from 2 to 7 among the mothers who experienced pain. Pain intensity before frenotomy was significantly higher than one month later after frenotomy. The mean pre-intervention pain score of the total sample was $6.33 \pm 2.56$ and $0.88 \pm 1.74$ at one month of life (Wilcoxon -4.75 , $p<0.01$ ). In the group of mothers who reported no breastfeeding pain at one month of life, the mean pain intensity decreased from $6.2 \pm 2.5$ before frenotomy to 0 (Wilcoxon -4.15, $p<0.01$ ). In mothers who still reported pain at one month of life, pain intensity also decreased, from $6.75 \pm 2.87$ before frenotomy to 3.63 \pm 1.6 at one month (Wilcoxon $-2.11, p=0.035$ ).
Table 2. Symptomatology in mothers and newborns with breastfeeding or mixed lactation associated with ankyloglossia before and after frenotomyc

\begin{tabular}{|c|c|c|c|c|c|}
\hline & \multicolumn{2}{|c|}{ Before frenotomy } & \multicolumn{2}{|c|}{$\begin{array}{c}\text { At one month of } \\
\text { life }\end{array}$} & \multirow{2}{*}{ McNemar } \\
\hline & $\mathbf{n}=\mathbf{3 3}$ & $\%$ & $\mathrm{n}=\mathbf{3 3}$ & $\%$ & \\
\hline $\begin{array}{l}\text { Difficulty } \\
\text { with } \\
\text { latching }\end{array}$ & 18 & 54.5 & 5 & 15.15 & $<0.01$ \\
\hline Jaundice & 6 & 18.2 & 0 & 0 & 0.031 \\
\hline $\begin{array}{l}\text { Weight } \\
\text { loss }\end{array}$ & 3 & 9.1 & 1 & 3 & 0.625 \\
\hline Pain & 29 & 87.9 & 8 & 24.24 & $<0.01$ \\
\hline $\begin{array}{l}\text { Cracked } \\
\text { nipples }\end{array}$ & 18 & 54.5 & 3 & 9 & $<0.01$ \\
\hline Mastitis & 0 & 0 & 1 & 3 & 1 \\
\hline
\end{tabular}

All the NBs showed weight gain: the mean weight was $4217 \mathrm{~g} \pm 781$ at one month of life (mean increase of $993.73 \mathrm{~g} \pm 576.37$ ). This weight gain in the first month of life was found in exclusively breastfed infants or mixed and artificial lactation. No differences were found among the groups (Kruskal Wallis 1.969, $p=0.374)$.

\section{Discussion}

This study demonstrates that ankyloglossia influences the correct initiation of breastfeeding and that an adequately indicated frenotomy has a positive impact on breastfeeding.

Ankyloglossia is a relatively frequent finding on the NBs physical examination, with a reported prevalence that varies between $<1 \%$ and $10 \%$ in the literature ${ }^{1,4,6,11-14}$. Also, this condition is more frequent in males ${ }^{4,7}$. In different studies, the prevalence of this condition varies 
because there is no clear definition of ankyloglossia and criteria indicating when a frenotomy should be performed ${ }^{15,16}$. This intervention was detected in $11.7 \%$ of NBs (36/305) in our center, with the most frequent type of frenulum being type II.

In this study, the prevalence of ankyloglossia was higher than that found in other studies. This study was carried out in a BFH, with expert staff in breastfeeding, where an exhaustive evaluation of breastfeeding is carried at the maternity ward during the entire stay of the mothers and the NBs, which allows diagnosing ankyloglossia early and intervening when necessary. It also allows to detect and treat those patients in whom ankyloglossia could go unnoticed, such as NBs with frenulum type IV, who are more challenging to diagnose, and in whom an under-diagnosis could lead to an abandonment of breastfeeding ${ }^{1,6,17}$. Ankyloglossia makes breastfeeding difficult ${ }^{1,8,14}$. Most NBs with ankyloglossia can initially breastfeed without great difficulty ${ }^{1}$, but problems related to breastfeeding, mainly pain, develop soon after.

We consider that the indication to perform a frenotomy should be associated with a correct evaluation by a breastfeeding specialist with subsequent follow-up. Frenotomy, evaluation by a breastfeeding specialist, and subsequent follow-up should be associated to ensure successful breastfeeding in NBs with ankyloglossia ${ }^{5,9}$. In our center, we also provide a written set of post-frenotomy rehabilitation exercises. However, the benefits of these exercises have not been demonstrated in any study ${ }^{10}$.

Coinciding with what has been published in other series, the symptom most frequently associated with ankyloglossia was moderate to intense breastfeeding-related pain ( $87.9 \%$ of the mothers) and the appearance of cracked nipples $(54.5 \%)^{8,17,18}$.

Breastfeeding-related pain tended to be high with frenulum type II $(p=0.096)$. Cracked nipples were more frequent in NBs with frenulum types II, III, and IV than with frenulum type I $(p=0.042)$. This finding may not be evaluable due to the small number of patients in each group. Furthermore, it should be considered that children with type I frenulum were operated on earlier than the other patients, so their mothers might not have developed the cracked nipples yet. However, no significant differences were found between the type of frenulum and the age at which frenotomy was performed.

The appearance of cracked nipples could be related to the sooner frenotomy in NBs with type I frenulum. Moreover, a later intervention was associated with a higher incidence of jaundice, a higher incidence of weight loss $>10 \%$, and mothers also presented pain more frequently, all of these differences being statistically significant ${ }^{1,19}$.

The complications secondary to frenotomy are bleeding, infection of the area, pain, tongue or submandibular duct injury, and recurrence ${ }^{9,12,20}$. In this series, only one NB presented pain; thus, it can be considered a safe technique in the hands of specialized personnel.

In the follow-up at one month of life, there was a statistically significant decrease in the number of patients presenting symptoms associated with breastfeeding. In addition, there was a decrease in the number of mothers with cracked nipples and pain. Most of them no longer presented pain, but those with pain reported mild intensity. These data coincide with those published in other series in which the main finding was a significant decrease in the number of mothers presenting pain and their pain scores ${ }^{12-14,20,21}$. After frenotomy, other aspects that improved were the presence of cracked nipples and difficulties in latching.

At one month of life, eight mothers abandoned breastfeeding, of which three stopped breastfeeding due to persistent difficulty in latching. This study did not evaluate other factors that could influence breast latching, which could be the subject for a future study. Another limitation encountered was the lack of a control group, which was not considered for ethical reasons.

We can conclude that ankyloglossia plays an essential role as a cause of breastfeeding difficulties. Although with a few complications, frenotomy is a simple intervention that significantly improves the difficulties presented. Also, this intervention should preferably be associated with evaluation and follow-up by a lactation specialist.

Finally, it is essential to carry out a more precise definition of the term ankyloglossia and standardize criteria for frenotomy.

\section{Ethical disclosures}

Protection of human and animal subjects. The authors declare that no experiments were performed on humans or animals for this study.

Confidentiality of data. The authors declare that they have followed the protocols of their work center on the publication of patient data.

Right to privacy and informed consent. The authors have obtained the written informed consent of the patients or subjects mentioned in the article. The corresponding author has this document. 


\section{Conflicts of interest}

The authors declare no conflict of interest.

\section{Funding}

None.

\section{References}

1. Messner AH, Lalakea ML, Aby J, Macmahon J, Bair E. Ankyloglossia: incidence and associated feeding difficulties. Arch Otolaryngol Head Neck Surg. 2000;126:36-9.

2. Coryllos $E$, Genna $C$, Salloum A. Congenital tongue-tie and its impact on breastfeeding. Breastfeeding: Best for baby and mother. Am Acad Pediatr. 2004:1-11.

3. Hazelbaker $A$. The assessment tool for lingual frenulum function (atlff): use in a lactation consultant private practice. Pasadena, CA: Pacific Oaks College; 1994.

4. Hall DM, Renfrew MJ. Tongue tie. Arch Dis Child. 2005;90:1211-5.

5. Schlatter SM, Schupp W, Otten JE, Harnisch S, Kunze M, Stavropoulou D, et al. The role of tongue-tie in breastfeeding problems-A prospective observational study. Acta Paediatr. 2019;108:2214-21.

6. Cinar F, Onat N. Prevalence and consequences of a forgotten entity: ankyloglossia. Plast Reconstr Surg. 2005:115:355-6.

7. González Jiménez D, Costa Romero M, Riaño Galán I, González Martínez MT, Rodríguez Pando MC, Lobete Prieto C. [Prevalence of ankyloglossia in newborns in Asturias (Spain)]. An Pediatr (Barc). 2014;81:115-9.

8. Ballard JL, Auer CE, Khoury JC. Ankyloglossia: assessment, incidence, and effect of frenuloplasty on the breastfeeding dyad. Pediatrics. 2002;110:e63.
9. Power RF, Murphy JF. Tongue-tie and frenotomy in infants with breastfeeding difficulties: achieving a balance. Arch Dis Child. 2015;100:489-94.

10. Pransky SM, Lago D, Hong P. Breastfeeding difficulties and oral cavity anomalies: the influence of posterior ankyloglossia and upper-lip ties. Int J Pediatr Otorhinolaryngol. 2015;79:1714-7.

11. Segal LM, Stephenson R, Dawes M, Feldman P. Prevalence, diagnosis, and treatment of ankyloglossia: methodologic review. Can Fam Physician. 2007:53:1027-33.

12. Hogan $M$, Westcott $C$, Griffiths $M$. Randomized, controlled trial of division of tongue-tie in infants with feeding problems. J Paediatr Child Health. 2005;41:246-50.

13. Ricke LA, Baker NJ, Madlon-Kay DJ, DeFor TA. Newborn tongue-tie: prevalence and effect on breastfeeding. J Am Board Fam Pract. 2005;18:1-7.

14. O'Shea JE, Foster JP, O'Donnell CP, Breathnach D, Jacobs SE Todd DA, et al. Frenotomy for tongue-tie in newborn infants. Cochrane Database Syst Rev. 2017;3:CD011065.

15. Messner AH, Lalakea ML. Ankyloglossia: controversies in management. Int J Pediatr Otorhinolaryngol. 2000;54:123-31.

16. Mills N, Pransky SM, Geddes DT, Mirjalili SA. What is a tongue tie? Defining the anatomy of the in-situ lingual frenulum. Clin Anat. 2019;32:749-61.

17. Walsh J, Tunkel D. Diagnosis and treatment of ankyloglossia in newborns and infants: a review. JAMA Otolaryngol Head Neck Surg. 2017;143:1032-9.

18. Lalakea ML, Messner AH. Ankyloglossia: does it matter? Pediatr Clin North Am. 2003:50:381-97.

19. Redondo-Secano J, Carrillo-Arroyo I, Delgado-Muñoz M, Alba-Romero C, Martí Carrera E, Gómez-Fraile A. Anquiloglosia neonatal. ¿Existe un exceso de indicación intervencionista? Acta Pediatr Esp. 2016;74:45-9.

20. Dollberg S, Botzer E, Grunis E, Mimouni FB. Immediate nipple pain relief after frenotomy in breastfed infants with ankyloglossia: a randomized, prospective study. J Pediatr Surg. 2006;41:1598-600.

21. Forlenza GP, Paradise Black NM, McNamara EG, Sullivan SE. Ankyloglossia, exclusive breastfeeding, and failure to thrive. Pediatrics. 2010;125:e1500-4 